University of Nebraska - Lincoln

DigitalCommons@University of Nebraska - Lincoln

\title{
Conventional and glyphosate-resistant maize yields across plant densities in single- and twin-row configurations
}

\author{
Kipling S. Balkcom \\ USDA-ARS, kip.balkcom@ars.usda.gov \\ Jason L. Satterwhite \\ Auburn University \\ Francisco J. Arriaga \\ USDA-ARS \\ Andrew J. Price \\ USDA-ARS \\ Edzard Van Santen \\ Auburn University
}

Follow this and additional works at: https://digitalcommons.unl.edu/usdaarsfacpub

Part of the Agricultural Science Commons

Balkcom, Kipling S.; Satterwhite, Jason L.; Arriaga, Francisco J.; Price, Andrew J.; and Van Santen, Edzard, "Conventional and glyphosate-resistant maize yields across plant densities in single- and twin-row configurations" (2011). Publications from USDA-ARS / UNL Faculty. 831.

https://digitalcommons.unl.edu/usdaarsfacpub/831

This Article is brought to you for free and open access by the U.S. Department of Agriculture: Agricultural Research Service, Lincoln, Nebraska at DigitalCommons@University of Nebraska - Lincoln. It has been accepted for inclusion in Publications from USDA-ARS / UNL Faculty by an authorized administrator of DigitalCommons@University of Nebraska - Lincoln. 


\title{
Conventional and glyphosate-resistant maize yields across plant densities in single- and twin-row configurations
}

\author{
Kipling S. Balkcom ${ }^{\mathrm{a}, *}$, Jason L. Satterwhite ${ }^{\mathrm{b}}$, Francisco J. Arriaga ${ }^{\mathrm{a}}$, Andrew J. Price ${ }^{\mathrm{a}}$, Edzard Van Santen ${ }^{\mathrm{b}}$ \\ a USDA-ARS, National Soil Dynamics Laboratory, 411 S. Donahue Dr., Auburn, AL 36832, United States \\ ${ }^{\mathrm{b}}$ Department of Agronomy and Soils, 201 Funchess Hall, Auburn University, AL 36849, United States
}

\section{A R T I C L E I N F O}

\section{Article history:}

Received 31 August 2010

Received in revised form 31 October 2010

Accepted 31 October 2010

\section{Keywords:}

Conservation systems

Cover crop

Oat

Rye

\begin{abstract}
A B S T R A C T
Maize (Zea mays L.) produced in narrow rows can increase yields and accelerate canopy closure. Costly equipment modifications make narrow rows impractical, but a twin-row configuration may boost production with fewer equipment modifications. Four field experiments were conducted to measure weed biomass, leaf area index (LAI), and yield for a conventional (CN) and a glyphosate-resistant (GR) hybrid across three plant densities (low 4.0-4.4 plants $\mathrm{m}^{-2}$; medium 5.9-6.4 plants $\mathrm{m}^{-2}$; and high 7.9-8.4 plants $\mathrm{m}^{-2}$ ) and two row configurations (single vs. twin) in a conservation tillage system during the 2005 growing season. The experimental design was a split-split plot with a RCB arrangement of whole plots where hybrids were assigned to main plots, row configurations to subplots, and plant density to sub-subplots with four replications. Row configuration had little effect on weed biomass compared to plant density and hybrid. Leaf area index increased with higher plant density at all locations. In general, LAI increased with the twin-row configuration, but LAI also varied with hybrid based on interactions between hybrid and plant density or row configuration. Row configuration had little impact on maize yields, while plant density had the most effect on yields. Plant density also interacted with hybrid or row configuration at multiple locations, although maize yields did not always increase with higher plant density. Conventional hybrids may also provide an alternative to GR hybrids, particularly at lower plant densities. Maize yield increases with twin rows were minimal and may not justify twin row conversion under dryland conditions, but growers that already utilize twin-row equipment will not suffer yield decreases by planting twin rows.
\end{abstract}

Published by Elsevier B.V.

\section{Introduction}

Maize production can benefit from altering agronomic practices, such as reducing row widths. Numerous studies have reported that decreasing row widths can decrease early season weed competition by promoting quicker canopy closure (Norsworthy and Oliveira, 2004; Shrestha et al., 2001; Teasdale, 1995). As crop row widths decrease, less light transmission to the soil surface diminishes weed emergence and creates an advantage for the crop (Forcella et al., 1992; Shrestha et al., 2001; Teasdale, 1995; Tharp and Kells, 2001).

In addition to decreasing weed competition, narrow rows can also increase maize yields through increased maize growth. Increased light interception by the maize canopy in narrow rows translates into greater early season growth and quicker canopy closure (Bullock et al., 1988; Teasdale, 1995). Porter et al. (1997) reported a $7 \%$ yield increase by narrowing $76 \mathrm{~cm}$ rows to either 51 or $25 \mathrm{~cm}$ rows averaged over 9 site-years; however, there was

\footnotetext{
* Corresponding author. Tel.: +1 3348444666.

E-mail address: kip.balkcom@ars.usda.gov (K.S. Balkcom).
}

no advantage for $25 \mathrm{~cm}$ row conversion, due to harvest and equipment limitations. Nielsen (1988) showed a $2.7 \%$ increase for maize planted in $38 \mathrm{~cm}$ rows compared to $76 \mathrm{~cm}$ rows across 9 locations. Widdicombe and Thelen (2002) reported 2 and 4\% maize yield increases across two separate growing seasons when rows were reduced from $76 \mathrm{~cm}$ to 56 and $38 \mathrm{~cm}$. Other research indicates no yield advantage when maize is planted in narrow rows (Farnham, 2001; Johnson et al., 1998).

Narrow row maize production dictates that plant density must also be considered. As row width narrows, plant density can be increased to achieve a more equidistant spacing to reduce competition among plants (Farnham, 2001). There is a limit to increasing plant density where interplant competition for light, water, and nutrients can reduce yields (Bullock et al., 1988; Duncan, 1984). However, the magnitude of this competition on yield varies with environment and genotype (Duncan, 1984).

Previous reports indicate that differences between hybrids can affect maize response in narrow rows. Farnham (2001) reported that certain hybrids may perform better in narrow rows based on relative maturity. Farnham (2001) examined six hybrids and found that later maturing hybrids appeared to perform better across 
narrow rows, but earlier maturity hybrids were more suited to traditional row spacings. This response was unexpected, since early maturing hybrids with their narrow leaf architecture would be expected to perform better in a narrow row environment, while the full canopy associated with later maturing hybrids would be more appropriate for wide row spacings (Farnham, 2001). In contrast, Westgate et al. (1997) indicated that hybrids capable of altering leaf display angles or whorled leaves might perform better in narrow rows. However, Westgate et al. (1997) also stated hybrids that perform well at high plant densities will also perform well as row spacings decrease due to no interactions observed between hybrid and row spacings or row spacings and plant densities (Nielsen, 1988; Ottman and Welch, 1989). Previous hybrid work has focused on comparisons between different hybrid characteristics discussed above, but none have compared hybrids with different genetic traits.

Data also suggest that maize yield increases attributed to narrow rows are greatest in northern locations and diminish as research trials are conducted further south (Farnham, 2001; Widdicombe and Thelen, 2002). These differences are implied to pertain to differences between the Northern and Southern U.S. Maize Belt. This indicates potential problems may arise when attempting to grow narrow row maize in the Southeast much farther south than the traditional U.S. Maize Belt. Southeastern soils are typically highly degraded Ultisols characterized by coarse textures, poor structure, and low organic matter contents ( $<1.0 \%)$, which contributes to limited water holding capacities (Radcliffe et al., 1988). Low water holding capacities of southern soils could limit the feasibility of increasing plant densities and decreasing row widths due to interplant competition.

One production practice that Southeast growers may utilize to offset poor regional soils are conservation systems that utilize a high residue cover crop. Langdale et al. (1990) and Reeves (1997) indicated that utilizing a conservation system on highly degraded soils may improve those soils physically, chemically, and biologically. The cover crop, a key component of a conservation system, provides several advantages for soils in this region. Cover crop residue has been shown to improve soil structure, water-holding capacity, and water infiltration attributed to slight increases in organic matter content (Dabney, 1998; Dabney et al., 2001; Truman et al., 2003). In addition, Hanson et al. (1993) and Roberts et al. (1998) showed that cover crops, particularly legumes, can be profitable for maize in traditional row spacings. Residues can also act as a physical barrier or mulch, limiting sunlight needed for weedseed germination and releasing allelopathic chemicals that reduce early season weed growth before canopy closure (Price et al., 2006; Reeves et al., 2005; Teasdale and Mohler, 2000). High residue conservation systems may increase the feasibility of narrow row maize production in the Southeast especially in dryland production, but the cost of conversion may limit grower adoption. Lambert and Lowenberg-Deboer (2001) acknowledged that yield increases associated with narrow rows may be insignificant compared to the cost of conversion.

An alternative to planting narrow rows, while maintaining many of the benefits, is a twin-row planting configuration (Karlen and Camp, 1985). A twin-row system will allow under the row subsoiling, which is necessary across Coastal Plain soils, and fertilization and harvesting can be accomplished with standard equipment (Karlen and Camp, 1985; Karlen et al., 1987). In the southeastern United States, maize is a good rotation crop for peanut (Arachis hypogea L.) (Johnson et al., 1999). In addition, previous work has investigated the benefits of twin-row peanut production, especially from a pest management standpoint leading to the adoption of twin-row peanut production (Balkcom et al., 2010; Culbreath et al., 2008; Lanier et al., 2004). There is also research underway exploring the benefits of twin-row cotton (Gossypium hirsutum L.) produc- tion in the Southeast (Reddy and Boykin, 2010). Fewer equipment modifications are required for a crop grown in a twin-row configuration, and growers that currently utilize a twin-row planter for an existing crop could adopt this practice easily while spreading equipment costs across multiple crops. Therefore, our objective was to examine how maize hybrid, row configuration, and plant density affected weed biomass, leaf area index (LAI), and maize grain yield in a conservation system.

\section{Materials and methods}

\subsection{Site description}

A field experiment was conducted during the 2005 growing season at the Gulf Coast Research and Extension Center (GCS) in Fairhope, $\mathrm{AL}\left(30^{\circ} 32^{\prime} \mathrm{N}, 87^{\circ} 52^{\prime} \mathrm{W}\right)$, the Tennessee Valley Research and Extension Center (TVS) in Belle Mina, AL (34 $41^{\prime} \mathrm{N}, 86^{\circ} 53^{\prime} \mathrm{W}$ ), the West Florida Research and Education Center (WFREC) in Jay, $\mathrm{FL}\left(30^{\circ} 46^{\prime} \mathrm{N}, 87^{\circ} 8^{\prime} \mathrm{W}\right)$, and the Wiregrass Research and Extension Center (WGS) in Headland, AL ( $\left.31^{\circ} 21^{\prime} \mathrm{N}, 85^{\circ} 19^{\prime} \mathrm{W}\right)$. Soil types at each location corresponded to a Malbis sandy loam (fine-loamy, kaolinitic, thermic Typic Kandiudult) at GCS, Red Bay sandy loam (fine-loamy, kaolinitic, thermic, Rhodic Kandiudult) at WFREC, Decatur silt loam (fine, kaolinitic, thermic Rhodic Paleudult) at TVS, and Dothan sandy loam (fine-loamy, kaolinitic, thermic Plinthic Kandiudult) at WGS.

The experimental design was a split-split plot with a RCB arrangement of whole plots $(r=4)$. Conventional $(\mathrm{CN})$ or glyphosate resistant (GR) hybrids were assigned to main plots, single- or twin-row configurations to subplots, and low (4.0-4.4 plants $\mathrm{m}^{-2}$ ), medium (5.9-6.4 plants $\mathrm{m}^{-2}$ ) and high (7.9-8.4 plants $\mathrm{m}^{-2}$ ) plant densities to sub-sub plots. Sub-sub plot dimensions for GCS and TVS were $15.2 \mathrm{~m}$ by $3.0 \mathrm{~m}$. Single rows were spaced $76 \mathrm{~cm}$ apart and twin rows were spaced $19 \mathrm{~cm}$ apart on $76 \mathrm{~cm}$ centers. Plot dimensions for WFREC and WGS were $15.2 \mathrm{~m}$ by $3.7 \mathrm{~m}$ with single rows spaced $91 \mathrm{~cm}$ apart and twin rows spaced $19 \mathrm{~cm}$ apart on $91 \mathrm{~cm}$ centers.

Hybrids utilized at each location were selected from the same parent line to minimize genetic differences among hybrids and restrict the major hybrid difference to the specified genetic trait (i.e., herbicide technology). Two parent lines were chosen because of known environmental differences between northern Alabama, southern Alabama and northern Florida. The parent line chosen for northern Alabama was from Pioneer (Pioneer; Johnston, IA) and included Pioneer $31 \mathrm{~N} 27^{\circledR}$ as the $\mathrm{CN}$ hybrid and Pioneer $31 \mathrm{~N} 26^{\circledR}$ as the GR hybrid. In southern Alabama and northern Florida, Dekalb (Dekalb Genetics Corporation; Dekalb, IL) was chosen as the parent line and consisted of DK697 ${ }^{\circledR}$ as the CN hybrid and DKC $69-72^{\circledR}$ as the GR hybrid.

All four locations utilized a conservation system that included a rye (Secale cereale L.) or oat (Avena sativa L.) cover crop established with a no-till drill seeded at $100 \mathrm{~kg} \mathrm{ha}^{-1}$ in November of 2004 . Cover crops were terminated with glyphosate [isopropylamine salt of $\mathrm{N}$ (phosphonomethyl) glycine] at least 2 week prior to maize planting. Biomass samples were determined immediately prior to chemical termination by cutting all aboveground tissue from two random $0.25 \mathrm{~m}^{2}$ areas within each plot, drying at $55^{\circ} \mathrm{C}$ for $72 \mathrm{~h}$, and weighing. Cover crop termination timing was not based on growth stage, but corresponded to anticipated maize planting date to allow maximum biomass production and soil moisture recharge with natural rainfall (Balkcom et al., 2007; Dabney, 1998). All relevant information pertaining to the cover crops is summarized in Table 1.

Approximately $2 \mathrm{~d}$ prior to maize planting, all plots were in-row sub-soiled 35-40 cm deep with a KMC Generation I Rip-Strip (Kelly Manufacturing Co., Tifton, GA). This strip tillage configuration consisted of a coulter, shank, and pneumatic press wheels. Both maize 
Table 1

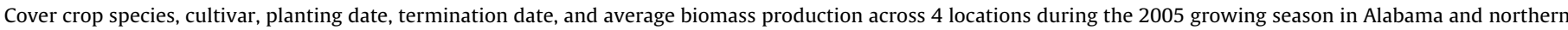
Florida.

\begin{tabular}{|c|c|c|c|c|c|}
\hline Location $^{\mathrm{a}}$ & Cover crop species & Cultivar & Planting date & Termination date & Biomass $\left(\mathrm{kg} \mathrm{ha}^{-1}\right)$ \\
\hline GCS & Rye & 'Wrens Abruzzi' & 17 November 2004 & 4 March 2005 & $1290(370)^{\mathrm{b}}$ \\
\hline TVS & Rye & 'Elbon' & 8 November 2004 & 29 March 2005 & $430(145)$ \\
\hline WFREC & Oat & 'Harrison' & 9 November 2004 & 4 March 2005 & $2350(470)$ \\
\hline WGS & Oat & 'Harrison' & 15 November 2004 & 7 March 2005 & $1250(235)$ \\
\hline
\end{tabular}

a GCS, Gulf Coast Research and Extension Center; TVS, Tennessee Valley Research and Extension Center; WFREC, West Florida Research and Extension Center; WGS, Wiregrass Research and Extension Center.

b Standard deviations in parentheses.

hybrids were seeded at the previously described plant densities for single- and twin-row configurations. Individual plant densities for both rows of the twin-row configuration were reduced by one half to match the equivalent plant density of the single-row configuration. Dates that correspond to all cultural practices including planting, spraying, harvesting, and sampling times for each location are summarized in Table 2. Single- and twin-row configurations were seeded with a Great Plains 1510P Precision Three-Point (Great Plains Manufacturing Inc., Salina, KS) planter at GCS and TVS. Single rows at WFREC and WGS were seeded with a John Deere 1700 MaxEmerge Plus (Deere \& Co., Moline, IL) planter equipped with Dawn (Dawn Equipment Co., Sycamore, IL) row cleaners. At WFREC, twin rows utilized the same planter; however, a shifter was attached to the tractor three-point hitch to offset the planter units and enable two passes of the row units to accomplish the twin-row configuration. The tractor was driven down the single-row plots again after the planting operation to eliminate differences associated with equipment traffic. At WGS, twin rows were seeded with a Monosem (Monosem Inc., Edwardsville, KS) twin row planter that had a coulter mounted in front of each individual row. The Great Plains 1510P Precision Planter did not have the capability to plant rows $>76 \mathrm{~cm}$; therefore, this planter could not be used at WFREC and WGS. Typical farm equipment (i.e. tractors, sprayers, combines) used at these two locations could not be altered for row spacing $<76 \mathrm{~cm}$; therefore, existing equipment at WFREC and WGS was utilized to manage this experiment with $91 \mathrm{~cm}$ rows.

Following typical weed control practices in each herbicide system, metolachlor [acetamide, 2-chloro-N-(2-ethyl-6methylphenyl)-N-(2-methoxy-1-methylethyl)-, (S)] was applied pre-emergence (PRE) to $\mathrm{CN}$ treatments. A single post-emergence (POST) application of atrazine(2-chloro-4-ethylamine-6isopropylamino-s-triazine) for the $\mathrm{CN}$ variety was used until the V7 growth stage. Glyphosate was applied within three weeks of planting at GCS and WGS, and approximately 6 weeks after planting at WFREC and TVS.
Weed biomass samples were taken prior to POST herbicide applications at all locations. Three samples were randomly collected from each plot under yield rows from a $0.25 \mathrm{~m}^{2}$ area. Samples were grouped by plot and oven dried at $55^{\circ} \mathrm{C}$ for $48 \mathrm{~h}$, prior to weighing. Leaf area index (LAI) readings were taken at two different times prior to canopy closure with a LI-COR 2000 Plant Canopy Analyzer (LI-COR, Inc., Lincoln, Nebraska). An additional third sampling time for LAI was included at GCS and WGS. Measurements were collected from one location in the middle of each plot using a $90^{\circ}$ angle cap. A reading was collected above the canopy and below the canopy with the wand perpendicular to the row.

Maize was harvested during August or September of 2005 using a mechanical combine except for WFREC, where $3.0 \mathrm{~m}$ sections were hand-harvested at 2 different locations within each plot due to severe lodging damage caused by Hurricane Dennis. All grain yields were adjusted to $155 \mathrm{~g} \mathrm{~kg}^{-1}$.

\subsection{Statistical analysis}

Data were analyzed with location in the model and there were significant location $\times$ treatment interactions across response variables. Weed biomass, LAI, and grain yield were analyzed based on a general linear mixed model procedure using SAS software, [release 9.2, SAS Institute Inc., Cary, NC; (Littell et al., 2006)] within each location, with data and discussion presented by location. Data were analyzed with replication, hybrid, row configuration, plant density, and the interactions among hybrid, row configuration, and plant density as fixed effects in the model, while replication $\times$ hybrid and replication $\times$ hybrid $\times$ row configuration were considered random. Fixed effects and interactions were considered different if $\operatorname{Pr}>F$ was $\leq 0.10$. Least significant difference (LSD) mean comparison tests were used to further distinguish differences between treatment means.

Table 2

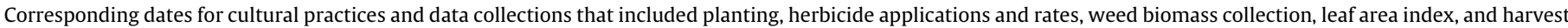
for four experimental locations during the 2005 growing season.

\begin{tabular}{|c|c|c|c|c|c|c|c|c|c|}
\hline \multirow[b]{2}{*}{ Location $^{\mathrm{a}}$} & \multirow[b]{2}{*}{ Planting date } & \multicolumn{3}{|c|}{ Herbicide summary } & \multirow[t]{2}{*}{ Weed biomass date } & \multicolumn{3}{|c|}{ Leaf area index } & \multirow[b]{2}{*}{ Harvest } \\
\hline & & Application date & Herbicide & Rate $\left(\mathrm{L} \mathrm{ha}^{-1}\right)$ & & Time 1 & Time 2 & Time 3 & \\
\hline & & 25 March & Metolachlor (CN) & 1.75 & & & & & \\
\hline \multirow[t]{3}{*}{ GCS } & 24 March & 15 April & Glyphosate (GR) & 1.75 & 14 April & 16 May & 25 May & 10 June & 19 August \\
\hline & & 13 May & Atrazine $(\mathrm{CN})$ & 4.68 & & & & & \\
\hline & & 15 April & Metolachlor (CN) & 1.17 & & & & & \\
\hline \multirow[t]{3}{*}{ TVS } & 15 April & 15 April & Glyphosate (GR) & 4.21 & 27 May & 29 May & 15 June & & 22 September \\
\hline & & 9 June & Atrazine $(\mathrm{CN})$ & 1.61 & & & & & \\
\hline & & 17 March & Metolachlor (CN) & 1.17 & & & & & \\
\hline \multirow[t]{3}{*}{ WFREC } & 16 March & 15 April & Glyphosate (GR) & 3.51 & 14 April & 19 May & 25 May & & 1 August \\
\hline & & 16 May & Atrazine $(\mathrm{CN})$ & 1.61 & & & & & \\
\hline & & 22 March & Metolachlor (CN) & 1.75 & & & & & \\
\hline \multirow[t]{2}{*}{ WGS } & $21 \mathrm{March}$ & 11 April & Glyphosate (GR) & 4.68 & 11 April & 1 June & 6 June & 13 June & 12 September \\
\hline & & 15 April & Atrazine $(\mathrm{CN})$ & 2.34 & & & & & \\
\hline
\end{tabular}

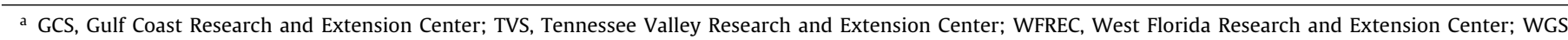
Wiregrass Research and Extension Center. 
Table 3

Rainfall distribution and totals measured during the 2005 growing season at four locations across Alabama and Florida.

\begin{tabular}{lcccc}
\hline & \multicolumn{4}{l}{ Location $^{\mathrm{a}}$} \\
\cline { 2 - 5 } Month & GCS $(\mathrm{mm})$ & TVS $(\mathrm{mm})$ & WFREC $(\mathrm{mm})$ & WGS $(\mathrm{mm})$ \\
\hline March & 43 & na $^{\mathrm{b}}$ & 199 & 89 \\
April & 508 & 28 & 309 & 203 \\
May & 189 & 30 & 80 & 60 \\
June & 282 & 85 & 175 & 247 \\
July & 125 & 157 & 453 & 136 \\
August & 131 & 82 & na & 201 \\
September & na & 0 & na & 22 \\
Total & 1278 & 382 & 1216 & 958
\end{tabular}

a GCS, Gulf Coast Research and Extension Center; TVS, Tennessee Valley Research and Extension Center; WFREC, West Florida Research and Extension Center; WGS, Wiregrass Research and Extension Center.

b Crop was either not planted or harvested during respective month, so no rainfall data are reported at respective location.

\section{Results and discussion}

\subsection{Climate data}

Rainfall amounts and distribution across all four locations during the 2005 growing season are shown in Table 3. Rainfall totals at GCS and WFREC were similar, but rainfall distributions were different, despite these locations being located close to each other $(\sim 120 \mathrm{~km})$. Rainfall distribution at GCS was plentiful each month and was characterized by a very wet month of April (Table 3 ). At WFREC, rainfall amounts were abundant, except for May, but July was extremely wet due to rainfall from Hurricane Dennis. Rainfall totals at both locations averaged $30 \%$ greater than rainfall received at WGS. Rainfall distribution at WGS was evenly distributed throughout the growing season, except for May. The lowest rainfall totals were recorded at TVS, and this total averaged $67 \%$ less than the other three locations (Table 3). The greatest rainfall received at TVS was recorded during July, which corresponds to a critical grain filling period for maize in the Southeast.

Locations ranged from northern Alabama to northern Florida and rainfall amounts and distribution across various soil types with different environmental conditions contributed to the requirement of our statistical analyses for all variables be performed by location. Although all experiments were conducted during one growing season, this scenario is similar to a study conducted at a single location across multiple growing seasons. Often, individual growing seasons can be drastically different, which requires analyses and interpretation of the results be performed by growing season (i.e. year). Data from our set of experiments represents four site-years of data, as opposed to typical field experiments at a single location that may only represent three site-years of information.

\subsection{Weed biomass}

Large crabgrass [Digitaria sanguinalis(L.) Scop.], sicklepod [Senna obtusifolia(L.) Irwin and Barnaby], smallflower morningglory, [Jacquemontia tamnifolia (L.) Griseb] and yellow nutsedges (Cyperus esculentusL.) were the dominant species at GCS. Bermudagrass
[Cynodon dactylon (L.) Pers.], large crabgrass, pitted morningglory, (Ipomoea lacunosa L.), prickly sida (Sida spinosa L.), and smooth pigweed (Amaranthus hybridus L.) were the dominant species at TVS. Large crabgrass, Texas panicum (Panicum texanumBuckl.), purple (C. rotundusL.) and yellow nutsedges, sicklepod, and Palmer amaranth (Amaranthus palmeri L.) were the dominant weed species present at WGS. Bermudagrass, Palmer amaranth, pitted morningglory, purple and yellow nutsedges, and sicklepod were the dominant weed species at WFREC. All POST herbicide applications were applied after weed biomass sampling with the exception of TVS (Table 2). By sampling prior to POST applications, early season weed pressure related to the effects of plant density, herbicide system associated with specific hybrids, and subsequent weed suppression of cover crop residues could be examined. Delaying herbicide applications can reduce yields due to weed competition (Dalley et al., 2004). Although glyphosate was applied PRE at TVS, it has no residual soil activity (Dalley et al., 2004), which enabled weed biomass evaluation, prior to POST applications at this location.

A difference in early season weed biomass levels was observed between hybrids at GCS $(P=0.0177)$ and TVS $(P=0.0002)$, although differences were not consistent across locations (Table 4). At GCS, weed biomass measured following a PRE application of metolachlor in the $\mathrm{CN}$ plots was 2.4 times greater than weed biomass measured from GR hybrid receiving no PRE herbicide (Table 4); however, weed biomass was relatively low reflecting the early season sampling, thus unlikely impacting yield (Teasdale and Mohler, 2000). Metolachlor was not effective in controlling weeds in $\mathrm{CN}$ plots at GCS; however, no PRE herbicides were applied in the GR plots, despite lower weed biomass values. Despite anticipated residual weed control, Norsworthy and Oliveira (2004) reported that densely accumulated seedbanks that contain species capable of emerging over a broad period can be difficult to control. At TVS, metolachlor provided excellent weed control prior to POST applications. Weed biomass measured across the GR hybrid plots was 22 times greater compared to weed biomass measured from $\mathrm{CN}$ hybrid plots (Table 4); however, weed biomass in both hybrid systems was again relatively low and not likely to impact yield. The superior control of metolachlor at TVS may be related to the limited cover crop biomass production at this location (Table 1). Previous research has shown that cover crop residues can interfere with soil reception of herbicides and reduce weed control (Banks and Robinson, 1982).

An interaction was observed between hybrids and row configurations $(P=0.0395)$ at WFREC. The PRE application of metolachlor reduced weed biomass $43 \%$ compared to no PRE herbicide (124 vs. $219 \mathrm{~kg} \mathrm{ha}^{-1}$ ) in the single-row configuration. In the twin-row configuration, there was no difference between hybrids, although the CN hybrid received PRE metolachlor. A comparison between row configurations within the GR hybrid showed a 31\% reduction (219 vs. $150 \mathrm{~kg} \mathrm{ha}^{-1}$ ) in weed biomass for the twin-row configuration. Although average weed biomass levels measured at this location were greater than levels previously discussed at GCS and TVS, weed suppression was apparent in the twin-row configuration. Previous studies have documented reduced weed biomass as row widths were reduced (Dalley et al., 2004; Forcella et al., 1992; Teasdale, 1995).

Table 4

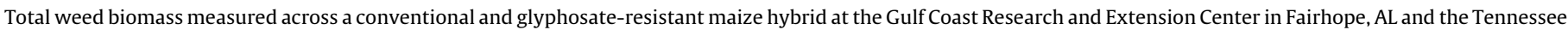
Valley Research and Extension Center in Belle Mina, AL during the 2005 growing season.

\begin{tabular}{|c|c|c|c|c|}
\hline & \multicolumn{2}{|l|}{$\mathrm{GCS}^{\mathrm{a}}$} & \multicolumn{2}{|l|}{ TVS $^{b}$} \\
\hline & Conventional maize $\left(\mathrm{kg} \mathrm{ha}^{-1}\right)$ & Glyphosate-resistant maize $\left(\mathrm{kg} \mathrm{ha}^{-1}\right)$ & Conventional maize $\left(\mathrm{kg} \mathrm{ha}^{-1}\right)$ & Glyphosate-resistant maize $\left(\mathrm{kg} \mathrm{ha}^{-1}\right)$ \\
\hline Weed biomass & 77.8 & 22.8 & 3.3 & 77.4 \\
\hline $\mathrm{LSD}_{0.10}$ & 29.4 & & 18.4 & \\
\hline
\end{tabular}

a GCS, Gulf Coast Research and Extension Center.

b TVS, Tennessee Valley Research and Extension Center. 
Table 5

Average leaf area index values measured in maize across plant densities at three locations during the 2005 growing season.

\begin{tabular}{llll}
\hline & \multicolumn{2}{l}{ Location $^{\mathrm{a}}$} & \\
\cline { 2 - 4 } Plant density $^{\mathrm{b}}$ & GCS $\left(\mathrm{m}^{2} \mathrm{~m}^{-2}\right)$ & TVS $\left(\mathrm{m}^{2} \mathrm{~m}^{-2}\right)$ & WFREC $\left(\mathrm{m}^{2} \mathrm{~m}^{-2}\right)$ \\
\hline Low & 1.52 & 2.17 & 1.62 \\
Medium & 1.88 & 2.57 & 1.92 \\
High & 2.09 & 2.74 & 2.17 \\
LSD $_{0.10}$ & 0.15 & 0.17 & 0.16 \\
\hline
\end{tabular}

a GCS, Gulf Coast Research and Extension Center; TVS, Tennessee Valley Research and Extension Center; WFREC, West Florida Research and Extension Center.

b Low (4.0-4.4 plants $\mathrm{m}^{-2}$ ); medium (5.9-6.4 plants $\mathrm{m}^{-2}$ ); high (7.9-8.4 plants $\left.\mathrm{m}^{-2}\right)$.

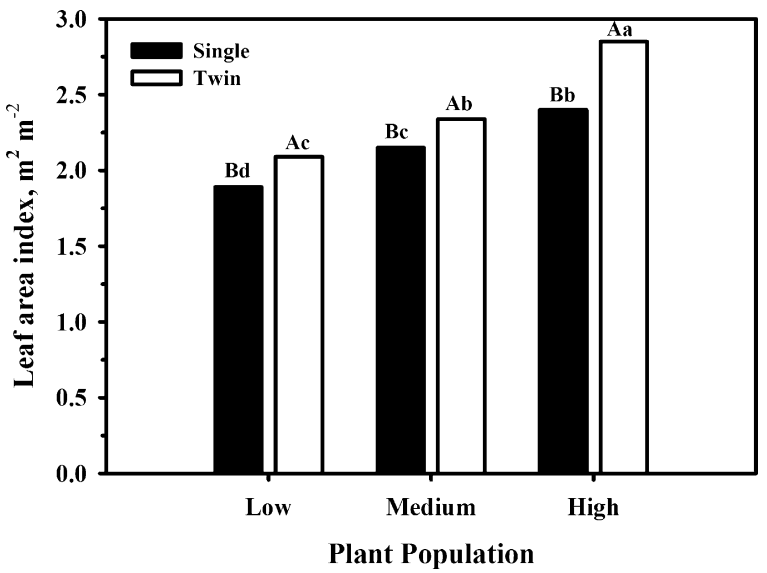

Fig. 1. Average leaf area index values measured across single and twin row configurations within low, (4.0-4.4 plants $\mathrm{m}^{-2}$ ); medium, (5.9-6.4 plants $\mathrm{m}^{-2}$ ); high (7.9-8.4 plants $\mathrm{m}^{-2}$ ) plant densities at the Wiregrass Research and Extension Center during the 2005 growing season. Capital letters compare row configurations within plant density; lowercase letters compare plant densities across or within row configurations.

\subsection{Leaf area index}

As expected, leaf area increased as plant density increased when averaged across hybrids and row configurations (Table 5). An interaction was observed between row configuration and plant density $(P=0.0173)$ at WGS, when averaged across hybrids. The twin-row configuration produced more leaf area compared to the single-row configuration across all plant densities with the greatest values recorded at the highest plant density (Fig. 1). Interestingly, leaf area measured in the twin-row configuration at the low plant density was equivalent to leaf area values in the single-row configuration at the medium plant density ( 2.09 vs. $2.15 \mathrm{~m}^{2} \mathrm{~m}^{-2}$; Fig. 1$)$. This was also observed for the twin-row configuration at the medium plant density compared to the single-row configuration at the high plant density ( 2.34 vs. $2.40 \mathrm{~m}^{2} \mathrm{~m}^{-2}$; Fig. 1 ). This finding supports previous research stating that decreased row widths allow the crop to utilize sunlight more efficiently due to increased leaf area (Bullock et al., 1998).

An interaction was also observed between maize hybrid and row configuration at GCS $(P=0.0789)$ and WGS $(P=0.0082)$ (Table 6). At GCS, the lowest LAI recorded was for the GR hybrid in the twin-row configuration, despite twin rows typically producing the highest leaf areas. In the twin-row configuration, leaf area measured in the GR hybrid was less than the CN hybrid (Table 6). Initially, it was suspected that early season weed pressure may have suppressed maize emergence prior to POST herbicide applications. As a result, maize leaf area would have been reduced because of early season weed pressure. However, weed biomass measured at GCS across the GR hybrid was reduced compared to the CN hybrid (Table 4). By eliminating early season weed pressure, the difference between LAI values at GCS could be related to canopy structure and leaf orientation between the CN and GR hybrids. Canopy architecture has been shown to differ among hybrids (Maddonni and Otegui, 1996). Cultural practices (i.e., plant density, row spacing) can also modify canopy architecture (Maddonni et al., 2001). For example, Girardin and Tollenaar (1994) reported that maize leaf orientation was more perpendicular to the row in the upper canopy at high plant densities compared to low densities. Leaf area values were lower from the GR hybrid at WGS, but the twin-row configuration produced the greatest leaf areas, regardless of hybrid at this location (Table 6).

\subsection{Maize grain yields}

Maize yields measured at WGS revealed an interaction between maize hybrid and row configuration $(P=0.0631)$. Maize yields were similar among each hybrid and row configuration, except for yields measured in the single row, GR hybrid combination. At the same location, this treatment combination also produced low LAI values (Table 6) which corresponded to reduced yields, implying that limited light interception lowered yields. Bullock et al. (1988) reported that increased yields in maize plants with equidistant spacing could be attributed to increased leaf area. However, other research indicates that maize production is more related to light utilization than light interception (Daughtry et al., 1983; Tollenaar and Bruulsema, 1988).

There was also an interaction between maize hybrid and plant density at TVS $(P=0.0063)$ and WGS $(P=0.0341)$. At both locations, the $\mathrm{CN}$ hybrid yielded higher than the GR hybrid at the low and medium plant densities, while no difference was observed at the high density (Table 7). At TVS, maize yields were $5 \%$ and $13 \%$ higher for the $\mathrm{CN}$ hybrid across the low and medium plant densities, while maize yields were $23 \%$ and $18 \%$ higher for the CN hybrid across the low and medium plant densities at WGS (Table 7). These results agree with conclusions presented by Karlen and Camp (1985) specifying plant densities should not surpass 7.0 plants $\mathrm{m}^{-2}$ for dryland maize production. This recommendation was based on results from conventional tillage plots, but under conditions of these experiments also applied to conservation tillage plots.

Table 6

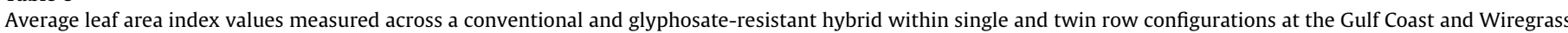
Research and Extension Centers during the 2005 growing season.

\begin{tabular}{|c|c|c|c|c|c|c|}
\hline \multirow[b]{2}{*}{ Row configuration } & \multicolumn{2}{|l|}{$\mathrm{GCS}^{\mathrm{a}}$} & \multirow[b]{2}{*}{$\begin{array}{l}\mathrm{LSD}_{0.10} \\
\left(\mathrm{~m}^{2} \mathrm{~m}^{-2}\right)\end{array}$} & \multicolumn{3}{|l|}{ WGS $^{\mathrm{b}}$} \\
\hline & $\begin{array}{l}\text { Conventional } \\
\text { hybrid }\left(\mathrm{m}^{2} \mathrm{~m}^{-2}\right)\end{array}$ & $\begin{array}{l}\text { Glyphosate-resistant } \\
\text { hybrid }\left(\mathrm{m}^{2} \mathrm{~m}^{-2}\right)\end{array}$ & & $\begin{array}{l}\text { Conventional } \\
\text { hybrid }\left(\mathrm{m}^{2} \mathrm{~m}^{-2}\right)\end{array}$ & $\begin{array}{l}\text { Glyphosate- } \\
\text { resistant hybrid } \\
\left(\mathrm{m}^{2} \mathrm{~m}^{-2}\right)\end{array}$ & $\begin{array}{l}\mathrm{LSD}_{0.10} \\
\left(\mathrm{~m}^{2} \mathrm{~m}^{-2}\right)\end{array}$ \\
\hline Single & 1.92 & 1.96 & 0.12 & 2.33 & 1.96 & 0.30 \\
\hline Twin & 1.80 & 1.65 & & 2.50 & 2.36 & \\
\hline $\mathrm{LSD}_{0.10}$ & 0.16 & & & 0.09 & & \\
\hline
\end{tabular}

a GCS, Gulf Coast Research and Extension Center.

b TVS, Wiregrass Research and Extension Center. 
Table 7

Maize grain yields measured across hybrids and plant densities at the Tennessee Valley and Wiregrass Research and Extension Centers during the 2005 growing season.

\begin{tabular}{|c|c|c|c|c|}
\hline \multirow[b]{2}{*}{ Location $^{\mathrm{a}}$} & \multicolumn{4}{|c|}{ Plant density } \\
\hline & $\begin{array}{l}\text { Low } \\
\left(\mathrm{kg} \mathrm{ha}^{-1}\right)\end{array}$ & $\begin{array}{l}\text { Medium } \\
\left(\mathrm{kg} \mathrm{ha}^{-1}\right)\end{array}$ & $\begin{array}{l}\text { High } \\
\left(\mathrm{kg} \mathrm{ha}^{-1}\right)\end{array}$ & $\begin{array}{l}\mathrm{LSD}_{0.10^{\mathrm{c}}} \\
\left(\mathrm{kg} \mathrm{ha}{ }^{-1}\right)\end{array}$ \\
\hline \multicolumn{5}{|l|}{ TVS } \\
\hline $\mathrm{CN}^{\mathrm{d}}$ & 7556 & 9903 & 9087 & 564 \\
\hline $\mathrm{GR}^{\mathrm{e}}$ & 7192 & 8742 & 9554 & \\
\hline $\mathrm{LSD}_{0.10}{ }^{\mathrm{f}}$ & & 564 & & \\
\hline \multicolumn{5}{|l|}{ WGS } \\
\hline $\mathrm{CN}$ & 7812 & 8669 & 8899 & 1044 \\
\hline GR & 6350 & 7370 & 9585 & \\
\hline $\mathrm{LSD}_{0.10}$ & & 1056 & & \\
\hline
\end{tabular}

a TVS, Tennessee Valley Research and Extension Center; WGS, Wiregrass Research and Extension Center.

b Low (4.0-4.4 plants $\mathrm{m}^{-2}$ ); medium (5.9-6.4 plants $\mathrm{m}^{-2}$ ); high (7.9-8.4 plants $\left.\mathrm{m}^{-2}\right)$.

c Compare any two means across plant densities and row configurations or hybrids.

d Conventional maize hybrid.

e Glyphosate-resistant maize hybrid.

f Compare any two means within the same plant density.

A comparison across plant densities and hybrids at TVS indicated that the highest yields were measured in the medium plant density for the $\mathrm{CN}$ hybrid, but the highest plant density produced the highest yield for the GR hybrid (Table 7). At WGS, lowest yields were observed in the low plant densities, regardless of hybrid, but there was no difference between low and medium plant densities (Table 7). The medium plant density produced equivalent yields to the high plant density, except for the GR hybrid. Maize yields from the GR hybrid, at the medium plant density, averaged $20 \%$ less yield compared to high plant density (Table 7).

This experiment only represents two sets of sister hybrids that contain or do not contain a gene for herbicide resistance. However, the GR hybrid did not appear to perform as well as the CN hybrid at the low and medium plant densities under the conditions of these experiments. Elmore et al. (2001) reported a $10 \%$ yield decrease for herbicide resistant cultivars compared to their non-herbicide resistant sister cultivar in soybean [Glycine max (L.) Merr.]. However, plant density was not a factor in this experiment and conventional tillage practices that did not include a cover crop were used. The increased flexibility of herbicide resistant crops allows POST herbicide applications to weeds, regardless of size (Tharp and Kells, 2001) which may have previously limited concerns related to how herbicide resistant hybrids perform compared to their non-resistant counterpart.

Row configuration interacted with plant density at GCS $(P=0.0268)$. Twin rows produced $16 \%$ greater maize yields compared to the single-row configuration at the highest plant density (Table 8). Maize yields averaged over row configurations at the

Table 8

Maize grain yields measured across row configurations and plant densities at the Gulf Coast Extension Center during the 2005 growing season.

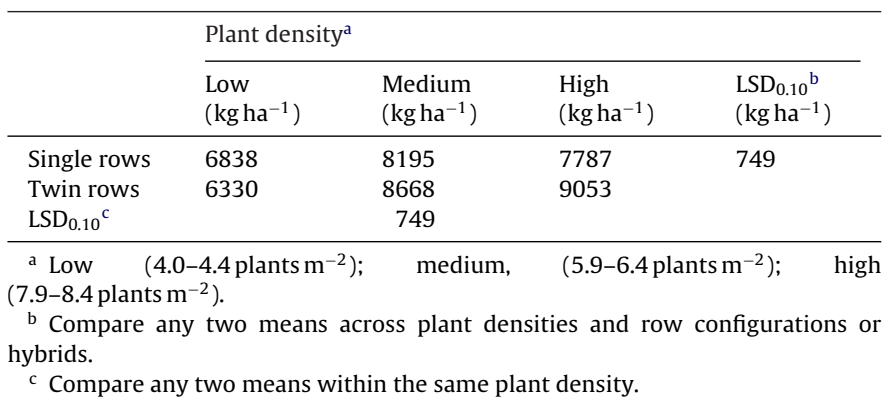

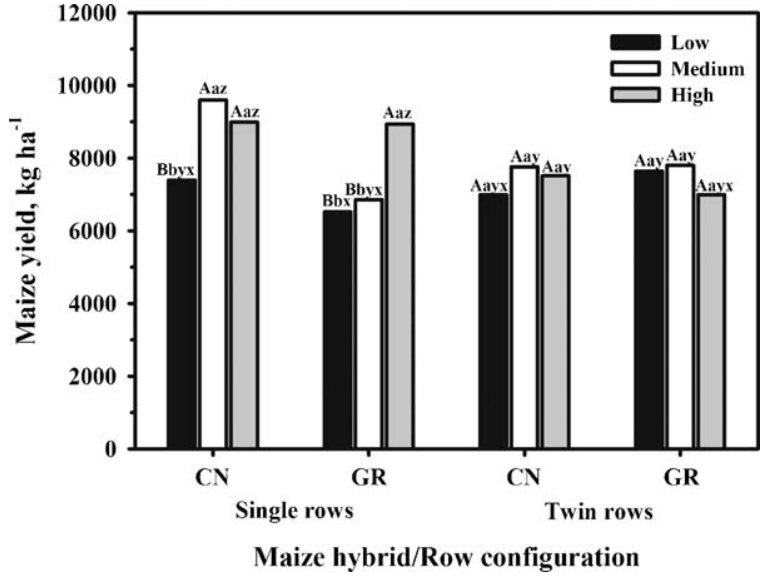

Fig. 2. Maize grain yields measured across conventional (CN) and glyphosateresistant (GR) hybrids, single- and twin-row configurations, and low (4.0-4.4 plants $\mathrm{m}^{-2}$ ), medium (5.9-6.4 plants $\mathrm{m}^{-2}$ ), and high (7.9-8.4 plants $\mathrm{m}^{-2}$ ) plant densities at the West Florida Research and Extension Center during the 2005 growing season. Capital letters are for comparing plant densities within a specific hybrid and row configuration; lowercase letters are for comparing any plant density and hybrid combination within each row configuration; reverse lowercase letters are for comparing any plant density across row configurations within $\mathrm{CN}$ and GR hybrids.

medium plant density were $28 \%$ higher than yields averaged over row configurations at the low plant density (Table 8). Maize yields were equivalent between medium and high plant densities within the same row configuration. However, twin-row maize at the high plant density yielded $10 \%$ greater than single-row maize at the medium plant density, while twin-row maize at the medium plant density yielded $11 \%$ greater than single-row maize at the high plant density (Table 8).

At WFREC, a 3-way interaction was observed between hybrids, row configurations, and plant densities $(P=0.0160)$. Differences among plant densities were only observed in the $\mathrm{CN}$ and GR hybrids for single rows (Fig. 2). Medium and high plant densities produced maize yields that averaged $26 \%$ greater than the low plant density for the CN hybrid, but maize yields in the high density were $34 \%$ greater than average yields produced in the low and medium plant densities for the GR hybrid. No yield differences were observed within the twin-row configuration across hybrids (Fig. 2). At the low and high plant density, both hybrids produced equivalent yields in single rows. Maize yields from the $\mathrm{CN}$ hybrid in single rows and medium plant density averaged $47 \%$ and $40 \%$ greater than GR hybrid yields at the low and medium plant densities in single rows (Fig. 2). The same observation was made when comparing $\mathrm{CN}$ hybrid yields at the high plant density to the GR hybrid in low and medium plant densities within single rows, but differences were somewhat less (Fig. 2). When observations were made across row configurations, it becomes apparent that single rows at the low and medium plant densities within the $\mathrm{CN}$ hybrid and the GR hybrid at the high plant density in single rows produced superior maize yields when compared to any twin-row combination (Fig. 2). Conventional maize yields in single rows at the low plant density were similar to all twin-row yields, regardless of hybrid or plant density.

Research indicates that a narrow row configuration requires increased plant densities combined with non-limiting soil moisture conditions to increase maize yields (Fulton, 1970; Karlen and Camp, 1985). Coarse textured soils utilized for maize production under dryland conditions would not be expected to support increased plant densities across any row configuration. Karlen and Camp (1985) reported maize yield reductions in the Atlantic Coastal Plain were attributed to erratic seasonal rainfall distribution and soils with low water holding capacities, despite average annual rain- 
fall exceeding $1100 \mathrm{~mm}$. Karlen and Camp (1985) did report an average yield increase of $640 \mathrm{~kg} \mathrm{ha}^{-1}$ for twin rows planted with conventional tillage, but plots were irrigated.

Employing conservation systems with high residue cover crops for reducing soil evaporation and increasing rainfall infiltration (Lascano et al., 1994) may increase the feasibility of greater plant densities and/or different row configurations. However, cover crop residue amounts produced at our locations averaged $1330 \mathrm{~kg} \mathrm{ha}^{-1}$ (Table 1 ), which is $70 \%$ below the minimum amount $\left(4500 \mathrm{~kg} \mathrm{ha}^{-1}\right.$ ) suggested by Reiter et al. (2008) to qualify as high residue. This is a common problem for maize production because this crop is typically planted early in the spring which dictates an early termination date that limits the cover crop growing season and subsequent biomass production (Balkcom and Reeves, 2005). Reduced accumulation of cover crop residue offsets potential soil moisture benefits thereby preventing this conservation system to consistently overcome moisture limiting conditions required to maximize yields for high populations in twin rows, although comparable yields were achieved in our study.

\section{Conclusions}

Dryland maize production across the Southeast is typically limited by soil moisture attributed to the prevalent coarse soil textures located across the region. Conservation tillage combined with a cover crop can help preserve soil moisture during short term droughts while simultaneously utilizing the residue for early season weed control. The combination of early season weed control and soil moisture conservation could allow plant densities to be increased alone or in conjunction with different row configurations. Furthermore, the use of $\mathrm{CN}$ maize hybrids could be advantageous for growers concerned about herbicide resistant weeds. Although not observed at each location, the twin-row configuration appeared to reduce early season weed biomass when no PRE herbicides were applied. Leaf area index increased across locations as plant density increased and generally increased in the twin-row configuration. At one location, the twin-row configuration at a lower plant density produced greater leaf area than the single-row configuration at the next highest plant density. In general, $\mathrm{CN}$ maize yields were equivalent or greater than GR maize yields, particularly at low and medium plant densities. The twin-row configuration provided no consistent yield advantage, which could indicate that soil moisture was still a limiting factor across these soil types for high yield potential in twin rows, despite the use of a cover crop. Although not examined in this study, we speculate that irrigated maize growers could benefit the most from increased plant densities in twin rows with a conservation system. The lack of consistent maize yield increases attributed to the twin-row configuration may not justify the conversion of dryland maize areas to twin rows, but growers that already utilize twin-row equipment for other crops (e.g., peanut, cotton) may consider planting maize in twin rows at plant densities $<7.0$ plants $\mathrm{m}^{-2}$ without suffering yield losses.

\section{Acknowledgements}

The authors would like to acknowledge the technical support provided by Jeffrey Walker, Agricultural Science Technician; Malcomb Pegues, Assistant Superintendent, Gulf Coast Research and Extension Center; Larry Wells, Superintendent, Wiregrass Research and Extension Center; Chet Norris, Superintendent, Tennessee Valley Research and Extension Center; and Doug Hatfield, Superintendent (retired), West Florida Research and Education Center.

\section{References}

Balkcom, K., Schomberg, H., Reeves, W., Clark, A., Baumhardt, L., Collins, H., Delgado, J., Duiker, S., Kaspar, T., Mitchell, J., 2007. Managing cover crops in conservation tillage systems. In: Clark, A. (Ed.), Managing Cover Crops Profitably, 3rd ed. Sustainable Agriculture Network, Beltsville, MD, pp. 44-61.

Balkcom, K.S., Reeves, D.W., 2005. Sunn-hemp utilized as a legume cover crop for corn production. Agron. J. 97, 26-31.

Balkcom, K.S., Arriaga, F.J., Balkcom, K.B., Boykin, D.L., 2010. Single- and twin-row peanut production within narrow and wide strip tillage systems. Agron. J. 102, 507-512.

Banks, P.A., Robinson, E.L., 1982. The influence of straw mulch on the soil reception and persistence of metribuzin. Weed Sci. 30, 164-168.

Bullock, D.G., Nielsen, R.L., Nyquist, W.E., 1988. A growth analysis comparison of corn grown in conventional and equidistant plant spacing. Crop Sci. 28, 254-258.

Bullock, D., Khan, S., Rayburn, A., 1998. Soybean yield response to narrow rows is largely due to enhanced early growth. Crop Sci. 38, 1011-1016.

Culbreath, A.K., Tillman, B.L., Gorbet, D.W., Holbrook, C.C., Nischwitz, C., 2008 Response of new field-resistant peanut cultivars to twin-row pattern or infurrow applications of phorate for management of spotted wilt. Plant Dis. 92, 1307-1312.

Dabney, S.M., 1998. Cover crop impacts on watershed hydrology. J. Soil Water Conserv. 53, 207-213.

Dabney, S.M., Delgado, J.A., Reeves, D.W., 2001. Using winter cover crops to improve soil and water quality. Commun. Soil Sci. Plant Anal. 37, 1221-1250.

Dalley, C.D., Kells, J.J., Renner, K.A., 2004. Effect of glyphosate application timing and row spacing on weed growth in corn (Zea mays) and soybean (Glycine max). Weed Technol. 18, 177-182.

Daughtry, C.S.T., Gallo, K.P., Bauer, M.E., 1983. Spectral estimates of solar radiation intercepted by corn canopies. Agron. J. 75, 527-531.

Duncan, W.G., 1984. A theory to explain the relationship between corn populations and grain yield. Crop Sci. 24, 1141-1145.

Elmore, R.W., Roeth, F.W., Nelson, L.A., Shapiro, C.A., Klein, R.N., Knezevic, S., Martin, Z.A., 2001. Glyphosate-resistant soybean cultivar yields compared with sister lines. Agron. J. 93, 408-412.

Farnham, D.E., 2001. Row spacing, plant density, and hybrid effects on corn grain yield and moisture. Agron. J. 93, 1049-1053.

Forcella, F., Westgate, M.E., Warnes, D.D., 1992. Effect of row width on herbicide and cultivation requirements in row crops. Am. J. Alter. Agric. 7, 161-167.

Fulton, J.M., 1970. Relationships among soil moisture stress, plant populations, row spacing, and yield of corn. Can. J. Plant Sci. 50, 31-38.

Girardin, P., Tollenaar, M., 1994. Effects of interference on maize leaf azimuth. Crop Sci. 34, 151-155.

Hanson, J.C., Lichtenberg, E., Decker, A.M., Clark, A.J., 1993. Profitability of no-tillage corn following a hairy vetch cover crop. J. Prod. Agric. 6, 432-437.

Johnson, A.W., Minton, N.A., Brenneman, T.B., Burton, G.W., Culbreath, A.K., Gascho G.J., Baker, S.H., Johnson III, W.C., 1999. Managing nematodes, fungal diseases, and thrips on peanut with pesticides and crop rotations of bahiagrass, corn, and cotton. Peanut Sci. 26, 32-39.

Johnson, G.A., Hoverstad, T.R., Greenwald, R.E., 1998. Integrated weed management using narrow corn row spacing, herbicides, and cultivation. Agron. J. 90, 40-46.

Karlen, D.L., Camp, C.R., 1985. Row spacing, plant population, and water management effects on corn in the Atlantic Coastal Plain. Agron. J. 77, 393-398.

Karlen, D.L., Kasperbauer, M.J., Zublena, J.P., 1987. Row-spacing effects on corn in the southeastern U.S. Appl. Agric. Res. 2, 65-73.

Lambert, D.M., Lowenberg-Deboer, J., 2001. Optimal row width for corn-soybean production. Staff Pap. 01-10 Dep. Agric. Econ., Purdue Univ. W. Lafayette, IN.

Langdale, G.W., Wilson, R.L., Bruce, R.R., 1990. Cropping frequencies to sustain longterm conservation tillage systems. Soil Sci. Soc. Am. J. 54, 193-198.

Lanier, J.E., Jordan, D.L., Spears, J.F., Wells, R., Johnson, P.D., Barnes, J.S., Hurt, C.A. Brandenburg, R.L., Bailey, J.E., 2004. Peanut response to planting pattern, row spacing, and irrigation. Agron. J. 96, 1066-1072.

Lascano, R.J., Baumhardt, R.L., Hicks, S.K., Heilman, J.L., 1994. Soil and plant water evaporation from strip tilled cotton: measurement and simulation. Agron. J. 86, 987-994.

Littell, R.C., Milliken, G.A., Stroup, W.W., Wolfinger, R.D., Schabenberger, O., 2006. SAS for Mixed Models, 2nd ed. SAS Institute Inc., Cary, NC.

Maddonni, G.A., Otegui, M.E., 1996. Leaf area, light interception, and crop development in maize. Field Crops Res. 48, 81-87.

Maddonni, G.A., Otegui, M.E., Cirilo, A.G., 2001. Plant population density, row spacing and hybrid effects on maize canopy architecture and light attenuation. Field Crops Res. 71, 183-193.

Nielsen, R.L., 1988. Influence of hybrids and plant density on grain yield and stalk breakage in corn grown in 15 -inch row spacing. J. Prod. Agric. 1 190-195.

Norsworthy, J.K., Oliveira, M.J., 2004. Comparison of the critical period for weed control in wide- and narrow-row corn. Weed Sci. 52, 802-807.

Ottman, M.J., Welch, L.F., 1989. Planting patterns and radiation interception, plant nutrient concentration, and yield in corn. Agron. J. 81, 167-174.

Porter, P.M., Hicks, D.R., Lueschen, W.E., Ford, J.H., Warnes, D.D., Hoverstad, T.R. 1997. Corn response to row width and plant population in the northern corn belt. J. Prod. Agric. 10, 293-300.

Price, A.J., Reeves, D.W., Patterson, M.G., 2006. Evaluation of weed control provided by three winter cereals in conservation-tillage soybean. Renew. Agric. Food Syst. $21,159-164$ 
Radcliffe, D.E., Tollner, E.W., Hargrove, W.L., Clark, R.L., Golabi, M.H., 1988. Effect of tillage practices on infiltration and soil strength of a Typic Hapludult soil after ten years. Soil Sci. Soc. Am. J. 52, 798-804

Reddy, K., Boykin, N.J.C., 2010. Weed control and yield comparisons of twin- and single-row glyphosate-resistant cotton production systems. Weed Technol. 24, 95-101.

Reeves, D.W., 1997. The role of soil organic matter in maintaining soil quality in continuous cropping systems. Soil Tillage Res. 43, 131-167.

Reeves, D.W., Price, A.J., Patterson, M.G., 2005. Evaluation of three winter cereals for weed control in conservation-tillage nontransgenic cotton. Weed Technol. 19, 731-736.

Reiter, M.S., Reeves, D.W., Burmester, C.H., 2008. Cotton nitrogen management in a high-residue conservation system: source, rate, method, and timing. Soil Sci Soc Am J. 72, 1330-1336.

Roberts, R.K., Larson, J.A., Tyler, D.D., Duck, B.N., Dillivan, K.D., 1998. Economic analysis of the effects of winter cover crops on no-tillage corn yield response to applied nitrogen. J. Soil Water Conserv. 53, 280-284.

Shrestha, A., Rajcan, I., Chandler, K., Swanton, C.J., 2001. An integrated weed management strategy for glufosinate-resistant corn (Zea mays). Weed Technol. 15, $517-522$.
Teasdale, J.R., 1995. Influence of narrow row/high population corn (Zea mays) on weed control and light transmittance. Weed Technol. 9, 113-118.

Teasdale, J.R., Mohler, C.L., 2000. The quantitative relationship between weed emergence and the physical properties of mulches. Weed Sci. 48 385-392.

Tharp, B.E., Kells, J.J., 2001. Effect of glufosinate-resistant corn (Zea mays) population and row spacing on light interception, corn yield, and common lambsquarters (Chenopodium album) growth. Weed Technol. 15, 413-418.

Tollenaar, M., Bruulsema, T.W., 1988. Efficiency of maize dry matter production during periods of complete leaf area expansion. Agron. J. 80, 580-585.

Truman, C.C., Reeves, D.W., Shaw, J.N., Motta, A.C., Burmester, C.H., Raper, R.L. Schwab, E.B., 2003. Tillage impacts on soil property, runoff, and soil loss variations from a Rhodic Paleudult under simulated rainfall. J. Soil Water Conserv. $58,258-267$.

Westgate, M.E., Forcella, F., Reicosky, D.C., Somsen, J., 1997. Rapid canopy closure for maize production in the northern US corn belt: radiation-use efficiency and grain yield. Field Crops Res. 49, 249-258.

Widdicombe, W.D., Thelen, K.D., 2002. Row width and plant density effects on corn grain production in the Northern Corn Belt. Agron. J. 94, 1020-1023. 